\title{
TINDAK TUTUR NIRGENDER DALAM TUTURAN BAHASA SASAK
}

\author{
Agus Darma Putra \\ Universitas Muhammadiyah Malang \\ Magister Pendidikan Bahasa Indonesia \\ agusdarmaputra01@gmail.com
}

\begin{abstract}
Abstrak
Penelitian ini bertujuan untuk menjelaskan: (1) tindak tutur nirgender dalam tuturan bahasa Sasak terkait dengan diksi; (2) tindak tutur nirgender dalam tuturan bahasa Sasak terkait dengan isi tuturan; dan (3) tindak tutur nirgender dalam tuturan bahasa Sasak terkait dengan topik tuturan. Pendekatan penelitian yang digunakan pada penelitian ini adalah pendekatan kualitatif dengan metode deskriptif. Berdasarkan hasil penelitian ditemukan tindak tutur nirgender dalam tuturan bahasa Sasak terkait dengan (1) diksi: umpatan, hujatan, sangkalan; (2) isi: pelabelan, pembatasan, diskriminasi; dan (3) topik tuturan dalam bidang pendidikan.
\end{abstract}

Kata Kunci: Tindak Tutur, Tuturan Nirgender, Penutur

\section{PENDAHULUAN}

Masyarakat Sasak khususnya pada kalangan perempuan secara tradisional masih diperlakukan berbeda dengan lakilaki. Diargumentasikan bahwa perempuan memiliki status dan peran yang berbeda dengan laki-laki pada kehidupan masyarakat Sasak. Peran perempuan Sasak lebih cenderung ke sektor domestik, sedangkan laki-laki Sasak bebas memilih pekerjaan lain (Khaerani, 2014). Perlakuan berbeda terhadap perempuan Sasak juga terdapat dalam penggunaan bahasa Sasak. Bahasa Sasak dikenal dengan tingkatan ragam bahasa yang terkontruksi oleh status sosial masyarakat. Hal tersebut membuat penutur perempuan dan penutur laki-laki menciptakan ragam bahasa yang berbeda. Ragam bahasa halus lebih cenderung digunakan oleh penutur perempuan sedangkan penutur laki-laki lebih bebas memilih ragam bahasa yang digunakan.

Wilian (2006) menyatakan dalam komunikasi sehari-hari masyarakat Sasak dikenal dengan dua bentuk ragam bahasa yang digunakan pada umumnya, yaitu ragam bahasa halus dan bahasa biasa (madya). Bahasa halus seperti: enggih, tiyang, pelinggih (iya, saya, anda), sedangkan bahasa Sasak biase (biasa) seperti: aok, aku, side (iya, aku, anda). Ragam bahasa tersebut diklasifikasikan 
berdasarkan status dan stratafikasi sosial masyarakat Sasak, yang keturunan menaq (bangsawan) dengan yang non bangsawan. Pemilihan ragam bahasa yang digunakan masyarakat Sasak dalam percakapan sehari-hari juga disebabkan oleh, status sosial, tingkat keakraban, faktor usia, situasi percakapan dan tingkat pendidikan masyarakat. Pemilihan ragam bahasa yang digunakan di masyarakat Sasak memunculkan fenomena-fenomena yang terjadi di masyarakat, terutama kepada penutur laki-laki terhadap penutur perempaun.

Fenomena yang sering terjadi di masyarakat Sasak adalah marginalisasi, kekerasan, dan pelecehan seksual terhadap perempuan. Fenomena yang lain adalah bentuk marginalisasi terhadap perempuan Sasak dalam dunia pendidikan. Secara tuturan masyarakat Sasak sering mengatakan "Lamun nine ndeq ne cocok lalo sekolah tinggi-tinggi, sengaq tetep yaq jari ineng kanaq daet isin pawon," (kalo perempuan tidak pantas pergi sekolah tinggi, karena tetap akan menjadi ibu rumah tangga dan bekerja di dapur). Tuturan tersebut menunjukan bahwa ada pembatasan yang terjadi terhadap perempuan di masyarakat Sasak.

Fenomena berikutnya adalah kekerasan dan pelecehan seksual terhadap perempuan yang sangat sering terjadi dan bahkan sudah dianggap lumrah. Terutama kekerasan dalam rumah tangga, dan pelecehan seksual yang biasa disebut oleh laki-laki terhadap perempuan, misalnya "Tolang tele ninaq" (alat kelamin perempuan). Penyebutan "alat kelamin perempuan" dalam tuturan merupakan ucapan yang sangat kasar. Fenomena kekerasan, dan pelecehan seksual terhadap perempuan Sasak masih sering terjadi. Menurut Bakri (2016) kenyataan yang terjadi pada masyarakat Sasak masih merendahkan perempuan, kekerasan dalam rumah tanggga, dan masalah pelecehan seksual.

Masalah-masalah ini muncul karena faktor gender yang membuat perempuan Sasak tidak bisa mendapatkan kedudukan yang setara dengan laki-laki. Nasri (2018) menyatakan peran perempuan Sasak lebih diutamakan untuk mengurus anak dan rumah tangga, sedangkan laki-laki sebagai kepala keluarga dan pengambil keputusan utama. Hal ini sesuai pandangan tradisional konservatif dan sosiokultural masyarakat Sasak. Dari hal tersebut, sudah bisa dilihat adanya bentuk perlakuan berbeda tehadap laki-laki dan perempuan Sasak. Bentuk perbedaan tersebut kerap didasari oleh perbedaan status sosial dan budaya, namun dalam penelitian ini tidak dibedakan berdasarkan hal tersebut atau diistilahkan dengan nirgender.

Istilah nirgender barasal dari nir dan gender. Nir merupakan bentuk terikat yang 
artinya tidak atau bukan, sedangkan gender artinya perbedaan peran perempuan dan laki-laki dari hasil konstruksi sosial (Depdiknas, 2005). Dengan demikian dapat diartikan bukan gender atau bukan didasarkan perbedaan laki-laki dan perempuan sebagai hasil konstruksi sosial dan budaya. Tindak tutur nirgender merupakan tindak tutur yang bukan didasarkan faktor gender, melainkan karena faktor situasi dan peristiwa tutur serta faktor sosial budaya masyarakat.

Penelitian terdahulu yang memfokuskan kajiannya pada gender dan bahasa Sasak dilakukan oleh Hidayat (2010) dengan judul "Bahasa Sasak Halus dan Perilaku Sosial Masyarakat Penuturnya". Penelitian tersebut berfokus pada penggunaan bahasa Sasak dan pengaruhnya terhadap perilaku masyarakat. Hasil penelitian menyatakan bahwa banyaknya masyarakat Sasak yang meninggalkan bahasa Sasak halus memicu terjadinya konflik antar anggota keluarga.

Penelitian dengan fokus yang mirip juga, dilakukan oleh Khaerani (2014) dengan judul "Potret Ketidakadilan Gender pada Masyarakat Tradisional Lombok". Penelitian tersebut berfokus pada bentuk ketidakadilan gender yang terjadi pada masyarakat tradisional Lombok (Sasak) . Hasil penelitian menggambarkan setidaknya terdapat lima macam bentuk ketidakadilan gender dalam masyarakat Sasak, yaitu beban ganda, subordinasi, stereotype, kekerasan, dan marginalisasi.

Penelitian terkait gender juga dilakukan oleh Bakri (2016) dengan judul "Analasis Percakapan Bahasa Sasak dalam Perspektif Gender: Sebuah Kajian Wacana Kritis". Pada penelitian tersebut digunakan teori wacana kritis model Norman Fairclough dan A. Van Dijk. Hasil penelitian menujukkan bahwa terdapat motif dan ideologi pada penutur sehingga lebih meninggikan peran laki-laki dari pada perempuan dalam perspektif gender yang memicu terjadinya persinggungan, pelecehan, dan kawincerai.

Kesamaan penelitian tersebut dengan penelitian ini adalah sama-sama menjadikan gender sebagai titik masalah utama, sedangkan perbedaannya terletak pada pengkarakteristikkan tindak tutur nirgender dalam tuturan bahasa Sasak, khususnya terkait dengan diksi, isi, dan topik tuturan. Untuk itu, Peneliti menggunakan beberapa teori tentang gender, tindak tutur, etnografi komunikasi, dan sosiolinugistik.

Dari beberapa paparan tersebut semakin menegaskan perlunya penelitian yang lebih mendalam tentang tindak tutur nirgender dalam tuturan bahasa Sasak. Adapun rumusan masalah dalam penelitian ini meliputi (1) bagaimanakah tindak tutur 
nirgender dalam tuturan bahasa Sasak terkait dengan diksi? (2) bagaimanakah tindak tutur nirgender dalam tuturan bahasa Sasak terkait dengan isi tuturan? dan (3) bagaimanakah tindak tutur nirgender dalam tuturan bahasa Sasak terkait dengan topik tuturan? Sesuai dengan rumusan masalah tersebut, maka penelitian ini dimaksudkan untuk (1) menjelaskan tindak tutur nirgender dalam tuturan bahasa Sasak terkait dengan diksi; (2) menjelaskan tindak tutur nirgender dalam tuturan bahasa Sasak terkait dengan isi tuturan; dan (3) menjelaskan tindak tutur nirgender dalam tuturan bahasa Sasak terkait dengan topik tuturan.

\section{KAJIAN TEORI}

Teori yang digunakan dalam penelitian ini sebagai alat analisis data dan untuk menjawab permasalahan yang ditemukan pada penelitian ini mencakup: (1) tindak tutur; (2) etnografi komunikasi; (3) sosiopragmatik; dan (4) gender.

\subsection{Teori Tindak Tutur}

Tindak tutur merupakan suatu tindakan berupa ujaran dalam sebuah percakapan. Tindak tutur dalam hal ini dapat terjadi dalam peristiwa tutur, dan peristiwa tutur tersebut terjadi dalam situasi tutur. Tindak tutur dibedakan dalam tiga katagori, yaitu: lokusi, ilokusi, dan perlokusi. Tindak tutur digunakan untuk menganalisis gejala tindakan yang terjadi di masyarakat tutur.
Tindak tutur melihat suatu gejala tindakan yang terjadi dalam peristiwa tutur yang dilakukan oleh penutur dalam situasi tutur (Sumarsono, 2010:181-182).

Tindak tutur lokusi merupakan tindak tutur yang mengucapkan sesuatu (ujaran) dengan makna yang sebenarnya. Wiranty (2015) menyatakan tindak tutur lokusi merupakan tindak tutur yang bersifat informatif dalam menyampaikan dan menyatakan sesuatu. Maksud dan tujuan dari tidak tutur lokusi adalah untuk menginformasikan sesuatu kepada lawan tutur, dan tanpa ada maksud dan tujuan tertentu. Artinya, tidak ada masud tersembunyi dalam tindak tutur lokusi.

Tindak tutur ilokusi merupakan tindak tutur yang melakukan sesuatu (tindakan), sekaligus hal tersebut menjadi masud dan fungsi dari tindakan tersebut. Tindak tutur ilokusi adalah tindak tutur yang menyampaikan atau menyatakan sesuatu disertai dengan tindakan dari penuturnya (Kentary dkk, 2015). Tindak tutur ilokusi digunakan untuk melakukan suatu tindakan dalam proses komunikasi.

Tindak tutur perlokusi merupakan tindak tutur yang memiliki hasil atau efek dari apa yang diujarakan terhadap pendengar atau lawan tutur. Wiranty (2015) menyatakan tindak tutur perlokusi merupakan tindak tutur yang memiliki efek atau pengaruh terhadap pendengar atau lawan tuturnya. Tindak tutur perlokusi 
biasanya memiliki maksud untuk mempengaruhi pendengar atau lawan tuturnya.

\subsection{Pendekatan Gender}

Gender merupakan sifat laki-laki dan perempuan, hasil kontruksi atau pengaruh sosial dan budaya masyarakat setempat. Sifat tersebut melekat kepada semua hal yang bisa dipertukarkan antara sifat perempuan dan laki-laki, dan sifat tersebut dapat berubah kapan saja. Sifat bentukan masyarakat dari hasil konstruksi sosial tersebut merupakan basis gender itu sendiri (Rokhimah, 2014). Sifat tersebut kemudian melahirkan anggapan tentang peran perempuan dan laki-laki di masyarakat secara sosial dan budaya. Hal tersebut juga melahirkan sebuah asumsi tentang pantas atau tidaknya peran dan kedudukan yang dilakukan oleh perempuan dan laki-laki dalam kehidupan sehari-hari dilingkup keluarga dan juga masyarakat.

Peran mengasuh anak atau sebagai ibu rumah tangga identik dengan perempuan, sedangkan peran dalam mencari nafkah identik dengan laki-laki atau peran seorang laki-laki (Mahmud, 2009:21). Perbedaan peran merupakan sebuah persepsi yang berasal dari lingkungan masyarakat atau hasil bentukan manusia. Artinya, perbedaan peran tersebut tidak bersifat kodrati, sehingga masih bisa untuk dipertukarkan. Perempuan bisa saja menjadi pencari nafkah, sebaliknya lakilaki bisa saja mengasuh anak. Peran tersebut bisa saja berubah seiring perkembangan zaman, dan mengikuti siklus kehidupan manusia di masyarakat.

Perbedaan peran sering menimbulkan permasalahan seperti kesenjangan atau ketidaksetaraan antara laki-laki dengan perempuan. Ketidaksetaraan tersebut menjadi pemicu permasalahan yang sering terjadi di masyarakat. Ketidaksetraan gender bisa terjadi diberbagai bidang, seperti: dalam bidang pendidikan, ekonomi, pekerjaan dan lain-lain. Ketidaksetaraan gender dalam berbagai bidang di masyarakat, tentu karena hasil konstruksi sosial budaya masyarakat setempat. Konstruksi social budaya masyarakat menimbulkan perbedaan peran antara laki-laki dengan perempuan. Perbedaan peren tersebut merupakan sesuatu yang dapat dipertukarkan dan dapat berubah kapan saja sesuai kesepakatan antara penutur perempuan dengan penutur laki-laki.

\subsection{Sosiopragmatik}

Sosiopragmatik merupakan ilmu yang mengkaji tentang penggunaan bahasa dalam interaksi social masyarakat. Nurjamily (2015) menyatakan sosiopragmatik merupakan bidang ilmu yang mengkaji tentang ujaran atau penggunaan bahasa di masyarakat, yang disesuaikan dengan kondisi dan situasi 
lingkungan masyarakat setempat. Permasalahan yang sering muncul dalam sosiopragmatik adalah prinsip-prinsip kerjasama dan kesantunan di dalam masyarakat multikultur atau beragam budaya. Sosiopragmatik menjadikan penggunaan bahasa dalam masyarakat sebagai titik atau pusat kajiannya. Kajian sosiopragmatik juga pada struktur bahasa secara eksternal yang merupakan factor social budaya masyarakat. Lebih khususnya, objek kajian sosiopragmatik adalah maksud dari sebuah ujaran atau tuturan yang digunakan masyarakat. Sosiopragmatik digunakan dalam penelitian ini untuk menelaah penggunaan bahasa di masyarakat tutur. Telaah tersebut dilakukan sesuai dengan kondisi pada masyarakat setempat.

\subsection{Pendekatan Etnografi Komunikasi}

Dalam penelitian entnografi komunikasi peran bahasa menjadi hal utama. Bahasa merupakan hal penting dalam komunikasi, atau menjadi inti dalam terjadinya proses komunikasi berlangsung. Terjadinya proses komunikasi antar manusia, terbentuklah kelompok-kelompok atau masyarakat, yang kemundian melahirkan kebudayaan. Etnografi Komunikasi merupakan penelitian tentang penggunaan bahasa pada komunikasi yang meliputi situasi, peristiwa, dan latar yang sesuai dengan budaya masyarakat tutur (Sunardi, 2015). Untuk itu dalam membentuk kebudayaan pada manusia, bahasa berperan aktif di dalamnya. Etnografi komunikasi dalam penelitian ini digunakan sebagai teori untuk mengkaji persoalanpersoalan yang ada di masyarakat tutur dan memiliki kaitan dengan topik penelitian.

\section{METODE PENELITIAN 3.1 Pendekatan Penelitian}

Penelitian ini menggunakan pendekatan kualitatif. Tujuannya untuk mempermudah dalam proses mendapatkan informasi atau tuturan dari masyarakat tutur yang didasarkan dari runtutan suatu persoalan atau kejadian, fenomena-fenomena, studi kasus, sosiokultural, dan mendeskripsikan data-data yang dihasilkan (Ulfatin, 2015:19).

\subsection{Metode Penelitian}

Metode yang digunakan dalam penelitian ini adalah metode deskriptif. Metode ini digunakan peneliti untuk menelaah fenomena berbahasa masyarakat Sasak. Tujuan dari metode deskriptif adalah untuk mendeskripsikan tentang fenomena yang diteliti (Djajasudarma, 2010:9). Dalam penelitian ini mendeskripsikan tentang fenomena berbahasa pada masyarakat Sasak.

\subsection{Sumber Data dan Data Penelitian}

Sumber data penelitian ini adalah percakapan dalam keluarga masyarakat 
Sasak, khususnya yang ada di Lombok Tengah. Masyarakat Sasak yang menjadi objek penelitian ini adalah keluarga suku Sasak. Objek penelitian tersebut, berada di Desa Ganti, Kecamatan Praya Timur, Kabupaten Lombok Tengah. Sumber data penelitian diambil dari empat keluarga, yang memiliki latar belakang berbedabeda. Data penelitian berupa tuturan nirgender yang diambil dari keluarga pertama, pada jam: 08:25-10:20 WITA, hari sabtu 09 maret 2019. Keluarga kedua, pada jam: 09:00-11:05 WITA, hari ahad 10 maret 2019. Keluarga ketiga, pada jam: 16:05-17:18 WITA, hari ahad 10 Maret 2019. Keluraga empat, pada jam: 09:10 WITA, hari selasa 12 Maret 2019.

\subsection{Teknik Pengumpulan Data}

Teknik pengumpulan data pada penelitian ini berupa teknik dokumentasi. Teknik dokumentasi tersebut digunakan karena sumber data dalam penelitian ini berupa transkripsi tuturan dalam komunikasi keluarga dari hasil menyimak dan mencatat. Teknik simak digunakan untuk menyimak tuturan (data) dari masyarakat Sasak. Teknik ini dilakukan dengan cara menyimak atau simak informasi berupa tuturan dari masyarakat tutur (Sudaryanto, 1988). Teknik catat digunakan untuk peneliti bisa mencatat semua tuturan dalam situasi tutur. Teknik ini sangat tepat digunakan dalam mengambil data tuturan pada keempat keluarga di masyarakat Sasak yang bersifat nirgender.

\subsection{Teknik Analisis Data}

Data diolah dengan teknik analisis data. Teknik analisis data merupakan sebuah cara yang digunakan sebagai pengolah data yang sudah dikumpulkan. Adapun pengolahan data meliputi: (a) mentraskripsikan data; mengklasifikasikan data; (c) menganalisis data; (d) mendeskripsikan data; dan (e) menginterpretasikan data.

\section{HASIL DAN PEMBAHASAN}

\subsection{Hasil Penelitian}

4.1.1 Tindak Tutur Nirgender dalam Tuturan Bahasa Sasak Terkait dengan Diksi

Berdasarkan hasil analisis data diperoleh tindak tutur nirgender dalam tuturan bahasa Sasak. Pilihan kata yang digunakan oleh penutur dalam interaksi sosial, sering berbeda dengan lawan tuturnya. Dalam pilihan kata tersebut terdapat tiga bentuk diksi nirgender yang digunakan penutur, yaitu (a) diksi berupa hujatan; (b) umpatan; dan (c) sangkalan, yang diuraikan berikut ini.

\subsubsection{Diksi Berupa Hujatan}

Tindak tutur nirgender dalam tuturan bahasa Sasak terkait dengan 
diksi, yang pertama terdapat bentuk hujatan kepada lawan tutur. Hujatan tersebut adalah perkataan yang tidak sopan kepada lawan tutur. Sesuai dengan data yang diperoleh sebagai berikut:

Pn 2: Endeng tolong sekali, baitan tiyang $\mathrm{Hp}$ koh (Tolong ambilkan Hpku!).

Pn 1: Aro ela o, kamong ton kembek (Enak saja ngomong, ambil sendiri!),

(K4/P1/Pn 2/Pn 1).

Data di atas merupakan percakapan keluarga, Penutur perempuan meminta tolong kepada penutur laki-laki menggunakan tuturan bahasa Sasak "Endeng tolong sekali, baitan tiyang HP koh" (Tolong ambilkan Hpku!). Pilihan kata 'tolong' yang artinya 'tolong' dan 'tiyang' yang artinya 'saya' merupakan jenis kata halus dan juga sopan namun, penutur laki-laki menjawab dengan menggunakan tuturan bahasa Sasak "Aro ela o, kamong ton kembek" (Enak saja ngomong, ambil sendiri!). Pilihan kata 'Ela o' yang artinya 'lidahmu' dan 'kamong' yang artinya 'kamu' merupakan jenis kata yang kasar. Dalam tuturan tersebut terdapat kekeran (verbal) dalam bentuk hujatan. Kekerasan (verbal) sering kali terjadi umumnya terhadap perempuan sebagai akibat dari perbedaan gender yang kemudian

menimbulkan

ketidaksetaraan gender (Khaerani, 2014). Tetapi dalam hal ini terjadi bukan karena faktor gender atau nirgender, melainkan karena konstruksi sosial budaya masyarakat Sasak bahwa laki-laki sudah biasa berbicara kasar kepada perempuan.

\subsubsection{Diksi Berupa Umpatan}

Tindak tutur nirgender dalam tuturan bahasa Sasak terkait dengan diksi, yang kedua ditemukan dalam bentuk umpatan. Umpatan tersebut, seperti yang terdapat dalam data berikut:

Pn 1: Tolang tele ninaq, keluwe raosm ('alat kelamin perempuan' jangan banyak bicara).

Pn 2: Kembekm jak, arak masalah ape? Ceritak maeh (Mengapa sih, ada masalah apa? Tolong jelaskan) (K4/P1/Pn 1/Pn 2).

Data di atas merupakan percakapan keluarga. Dalam hal ini penutur lakilaki dalam keadaan marah, dan menyampaikan tuturan bahasa Sasak "Tolang tele ninaq, keluwe raosm" ('alat kelamin perempuan' jangan banyak bicara), merupakan jenis tuturan yang kasar. Pilihan kata dalam frase 'tolang tele ninaq' (alat kelamin perempuan), merupakan jenis kata kasar yang seharusnya tidak boleh digunakan. Kemudian penutur perempuan 
menjawab ceritak maeh (tolong jelaskan) dengan sangat sopan dan juga santun. Dari tindak tutur tersebut, terdapat pilihat kata dan ragam bahasa yang berbeda dari kedua penutur. Penutur laki-laki menggunakan pilihan kata dan ragam bahasa yang kasar dalam bentuk umpatan, sedangkan perempuan lebih cenderung menggunakan pilihan kata dan ragam bahasa yang sopan. Perbedaan tersebut terjadi bukan kerena faktor gender atau peran, melainkan karena konstruksi sosial budaya dan faktor pendidikan penutur yang tidak pernah sekolah, sehingga terbiasa dalam menggunakan pilihan kata yang kasar. Nasri (2018) menyatakan perbedaan laki-laki dan perempuan adalah hal yang bersifat sosial budaya. Konstruksi sosial budaya menimbulkan tindak tutur nirgender.

\subsubsection{Diksi Berupa Sangkalan}

Tindak tutur nirgender dalam tuturan bahasa Sasak terkait dengan diksi, yang ketiga dalam bentuk sangkalan. Sangkalan yang digunakan penutur sering menggunakan pilihan kata yang kasar kepada lawan tuturnya. Adapun data yang diperoleh sebagai berikut:

Pn 2: Mene lamun masalah sak enuk jak (Begini, kalau masalah itu).
Pn 1: Kamong doang paling semelan, marak sak ketaon lalok, rengah koh bae juluk (Kamu itu bengel bangat, seperti orang yang lebih tahu saja, dengarkan saja dulu!) (K1/P1/Pn 2/Pn 1).

Pada data percakapan keluarga di atas, ada bentuk sangkalan dari penutur laki-laki kepada penutur perempuan. Sangkalan tersebut tentu memiliki maksud dan tujuan. Tujuan dari sangkalan tersebut adalah untuk didengarkan atau dituruti oleh lawan tutur (Bakri, 2016). Sangkalan tersebut menggunakan tuturan bahasa Sasak 'kamong doang paling semelan, marak sak ketaon lalok, rengah koh bae juluk' (kamu itu bengel bangat, seperti orang yang lebih tahu saja, dengarkan saja dulu!). Pilihan kata kamong (kamu) dan semelan (bengel), merupakan jenis kata kasar yang digunakan oleh penutur lakilaki kepada penutur perempuan. Meskipun demikian, penutur perempuan tidak melakukan sangkalan balik dengan pengucapan serupa. Kejadian tersebut ada bentuk tindak tutur nirgender dalam tuturan bahasa Sasak terkait dengan diksi yang digunakan kedua penutur. Hal tersebut terjadi karena faktor psikologis penutur laki-laki yang dalam situasi merasa kesal sama lawan tutur dan karena factor konstruksi social budaya. 
Konstruksi social masyarakat yang membuat penutur laki-laki terbiasa menggunakan kata-kata yang kasar.

\subsubsection{Tindak Tutur Nirgender dalam Tuturan Bahasa Sasak Terkait dengan Isi Tuturan}

Tindak tutur nirgender dalam tuturan bahasa Sasak terkait dengan isi tuturan, ditemukan tiga bentuk isi, yaitu: pelabelan, marginalisasi, dan diskriminasi. Ketiga bentuk isi tuturan tersebut, dipaparkan dengan lebih jelas di bawah ini.

\subsubsection{Pelabelan}

Bentuk tindak tutur nirgender dalam tuturan bahasa Sasak terkait dengan isi yang pertama adalah pelabelan. Pelabelan terhadap perempuan di masyarakat tradisional Sasak masih sangat sering terjadi. Ironisnya bentuk pelabelan yang didapatkan perempuan Sasak kebanyakan pelabelan negatif. Bentuk Pelabelan tersebut seperti yang ada pada data berikut:

Pn 1: Lamun dengan nine beremberembe ketinggi lain lalo sekolah, tetep yak begawean lek pawon dait jari inen kanak (Perempuan setinggi apapun sekolahnya, dia akan tetap bekerja di dapur dan menjadi ibu rumah tangga) (K1/P1/Pn 1).

Data di atas merupakan tuturan dari penutur laki-laki, dan diambil saat komunikasi antar keluarga berlangsung.
Dalam tuturan tersebut menujukan ada bentuk tindak tutur yang memberikan pelabelan terhadap perempuan Sasak. Dari pilihan kata yang digunakan oleh penutur laki-laki lek pawon (di dapur) dan inen kanak (ibu rumah tangga), mengidentikkan bahwa perempuan Sasak selalu ada di dapur dan menjadi ibu rumah tangga. Khaerani (2014) menyatakan perempuan Sasak identik dengan pekerjaan-pekerjaan rumah dan menjadi ibu rumah tangga. Sangat jarang ada perempuan Sasak yang bekerja di luar rumah, apalagi bisa mendapatkan kesempatan atau akses untuk menjadi perempuan karier. Hal tersebut sangat dibatasi oleh masyarakat Sasak terhadap perempuan.

\subsubsection{Marginalisasi}

Tindak tutur nirgender dalam tuturan bahasa Sasak terkait dengan isi tuturan yang kedua adalah marginalisasi. Dalam masyarakat Sasak ada bentuk marginalisasi yang terjadi terhadap penutur perempuan, seperti yang dikeluhkan penutur perempuan berikut ini.

Pn 2: Mule lamun nine ndek te pilu, dalem masalah raos-raos sak menong, atao ngeraos mupakat sak umum (Perempuan memang tidak dilibatkan, dalam membicarakan hal-hal yang bersifat umum) (K1/P1/Pn 2). 
Kutipan data di atas menggambarkan bentuk tindak tutur nirgender berupa marginalisasi terhadap penutur perempuan dalam bentuk tidak dilibatkannya perempuan. Marginalisasi tersebut terdapat dalam tuturan bahasa Sasak "Mule lamun nine ndek tepilu, dalem masalah raos-raos sak menong atao ngeraos mupakat sak umum" (Perempuan memang tidak dilibatkan, dalam membicarakan hal-hal yang bersifat umum). Lebih ditekankan lagi oleh penutur perempuan pada 'Ndek tepilu' (tidak dilibatkan), yang merupakan bentuk marginalisasi terhadap penutur perempuan. Marginalisasi terjadi karena adat dan budaya masyarakat yang tidak pernah melibatkan perempuan dalam mengambil keputusan, meskipun secara hak penutur perempuan juga berhak untuk ikut andil. Hak-hak yang seharusnya didapatkan oleh penutur perempuan malah diabaikan oleh penutur laki-laki, sehingga merugikan penutur perempuan (Juanda, 2018). Jadi, secara isi tuturan tersebut merupakan bentuk tindak tutur nirgender, karena terjadi bukan karena faktor gender namun karena adat dan budaya.

\subsubsection{Diskriminasi}

Tindak tutur nirgender dalam tuturan bahasa Sasak terkait dengan isi tuturan, yang ketiga adalah diskriminasi. Diskriminasi di masyarakat Sasak bukanlah hal baru, namun sudah sangat sering terjadi di masyarakat Sasak. Berdasarkan hasil penelitian, diskriminasi digambarkan berikut ini.

Pn 3: Amaq melekku lalo sekolah angenku malek (Aku ingin sekolah lagi ayah).

Pn 1: Ndek arak ceriten dengan nine lalo sekolah jaok-jaok, dait lalo sekolah tinggitinggi, seanden o mame jak dakak (Tidak ada ceritanya, perempuan sekolah jauhjauh, dan tinggi-tinggi, kalau laki-laki tidak masalah.) (K1/P1/Pn 3/Pn 1).

Berdasarkan data di atas diperoleh bentuk tindak tutur nirgender berupa diskriminasi dalam tuturan bahasa Sasak. Hal tersebut dapat dilihat dari bentuk larangan terhadap perempuan sebagai wujud perbedaan perlakuan kepada perempuan, pada kalimat "Ndek arak ceriten dengan nine lalo sekolah jaok-jaok, dait lalo sekolah tinggitinggi, seainden o mame jak dakak" (Menurut cerita, perempuan tidak boleh pergi sekolah jauh dari rumah, dan sekolah tinggi. Seandainya kamu seorang laki-laki tidak masalah). Tuturan tersebut digunakan oleh penutur laki-laki kepada penutur 
perempuan, dalam bentuk larangan.

Lebih ditekan lagi pada akhir kalimat "Seanden o mame jak dakak" (Seandainya kamu seorang laki-laki tidak masalah). Pilihan kata tersebut, menandakan ada bentuk diskriminasi. Adanya perlakuan berbeda terhadap penutur perempuan, membuatnya tidak bisa mendapatkan hak, akses, dan kedudukan yang sama dengan laki-laki. Kedudukan perempuan masih dianggap rendah dari laki-laki (Unsriana, 2014). Hal tersebut dikatagorikan sebagai bentuk tindak tutur nirgender berupa diskriminasi dalam tuturan bahasa Sasak, yang terjadi karena tradisi masyarakat.

\subsubsection{Tidak Tutur Nirgender dalam Tuturan Bahasa Sasak Terkait dengan Topik Tuturan}

Berdasarkan hasil penelitian ini ditemukan tiga macam topik tuturan yang merupakan tindak tutur nirgender dalam tuturan bahasa Sasak, yaitu: (a) dalam bidang pendidikan; pekerjaan; dan (c) partisipasi.

\subsubsection{Pendidikan}

Tindak tutur nirgender dalam tuturan bahasa Sasak terkait dengan topik tuturan, ditemukan dalam topik tentang pendidikan. Dalam masyarakat Sasak sering terjadi tindak tutur nirgender dalam topik tuturan tentang pendidikan, seperti pada data berikut:

Pn 4: Olek laek memang lamun masalah nuk jak, lamun laek jak kan, gak uning te kene "Eh kembe lalo sekolah nine paling pawon doang lain tutuk." jarin ndek tao ngelawan, lamun wah dengan toak kene meno. Nah, bede kance dengan mame, lamun dengan mame mbe-mbe lain mele lalo sekolah tebeng doang (Kalau masalah itu memang sudah dari duhulu, karena duhulu diperintahkan oleh orang tua "Perempuan tidak perlu sekolah, karena nanti akan tetap menjadi ibu rumah tangga." Jadi, tidak berani untuk melawan, jika orang tuanya sudah berbicara seperti itu. Sedangkan lakilaki, selalu diberikan kesempatan untuk sekolah) (K2/P1/Pn 4).

Data di atas menegaskan bahwa di masyarakat khususnya bagi perempuan Sasak masih kurangan akses, terutama dalam dunia pendidikan. Kurangnya akses untuk bisa menempuah pendidikan bagi perempuan tentu terjadi bukan tanpa alasan. Alasannya karena perempuan merupakan pengurus rumah tangga, sehingga tidak dibebankan dengan pendidikan (Natasha, 2013). Hal tersebut bisa terjadi karena faktor tradisi masyarakat yang masih kental. Di masyarakat Sasak memiliki tradisi yang selalu 
mengutamakan laki-laki dalam semua hal, termasuk dalam pendidikan. Oleh sebab itu, di masyarakat Sasak masih sangat minim sekali perempuan yang bisa menempuh pendidikan tinggi. Hal tersebut dikatagorikan sebagai tindak tutur nirgender karena topik tuturan tentang pendidikan didominasi oleh laki-laki karena faktor tradisi bukan karena gender.

\subsubsection{Pekerjaan}

Dalam bidang pekerjaan sering terjadi tindak tutur nirgender dalam tuturan bahasa Sasak terkait dengan topik tuturan. Topik tuturan yang dimaksud adalah bidang pekerjaan. Adapun data yang diperoleh sebagai berikut:

Pn 1: Ndek cocok dengan nine begawean lek luah, nggak taon cocok begawean lek bale. Sengak elek laek ye doang entan (Perempuan tidak pantas bekerja di luar, hanya pantas kerja di dalam rumah, karena memang sudah seperti itu sejak dahulu) (K3/P1/Pn 1).

Data di atas penutur laki-laki menyampaikan bahwa perempuan tidak pantas bekerja di luar rumah, dan hanya pantas menjadi ibu rumah tangga. Penutur laki-laki juga menyampaikan bahwa hal tersebut sudah seperti itu dari dulu. Artinya, keadaan tersebut merupakan hal yang wajib bagi perempaun Sasak yang hanya menjadi ibu rumah tangga atau bagian domistik. Yusrini (2017) menyatakan semua yang bersifat domistik selalu diidentikan sama perempuan. Mulai dari pekerjaan sebagai ibu rumah tangga, sampai semua kegiatan yang ada. Hal tersebut merupakan hasil dari konstruksi sosial dan tradisi yang ada di masyarakat, jadi bukan karena faktor gender.

\subsubsection{Partisipasi}

Berikutnya, tindak tutur nirgender terkait dengan topik tuturan sering juga terjadi dalam partisipasi perempuan. Perempuan Sasak sangat dibatasi oleh masyarakat, terutama dalam keikutsertaannya pada kegiatankegiatan yang ada di masyarakat setempat. Hal tersebut sesuai dengan data yang diperoleh peneliti, sebagi berikut:

Pn 2: Menurut tiyang jak, dengan nine Sasak nuk masih teteken atao ndek bebas wah aneh sengak masih takut lek dengan toak te. dait ndek te girang tepiluk lamun arak entan lek masyarakat, biasen dengan mame doang (Menurut saya sebagai perempuan Sasak, masih merasa diteken atau tidak marasa bebas karena kita masih takut sama orang tua. Tidak pernah diikutsertakan juga dalam acara masyarakat, biasanya laki-laki saja) (K2/P1/Pn 2). 
Pada data di atas penutur perempuan menekankan pada akhir tuturan 'dait ndek te girang tepiluk lamun arak entan lek masyarakat, biasen denagn mame doang' (Tidak pernah diikutsertakan juga dalam acara masyarakat, biasanya laki-laki saja). Artinya, penutur perempuan menyampaikan bahwa partisipasi perempaun Sasak sangat dibatasi. Berbeda dengan laki-laki yang selalu diikutsertakan dalam semua kegiatan di masyarakat. Hal tersebut terjadi karena banyak faktor, mulai dari faktor konstruksi sosial, budaya, tekanan, dan tidak memiliki keberanian untuk bersuara atau berpendapat. Menurut Nasri (2018) perempuan Sasak tidak memiliki keberanian dan kepercayaan diri untuk maju (berbicara), karena selalu mempersepsikan status dirinya berada dibawah status laki-laki. Untuk itu, perempuan Sasak selalu menunggu keputusan dari laki-laki dalam semua hal.

\subsection{Pembahasan}

4.2.1 Tindak Tutur Nirgender dalam Tuturan Bahasa Sasak Terkait dengan Diksi

Tindak tutur nirgender dalam tuturan bahasa Sasak terkait dengan diksi, ditemukan jenis diksi yang menyatakan: hujatan, umpatan, dan sangkalan. Diksi hujatan memiliki maksud untuk menolak permintaan lawan tutur (Perempuan). Penutur lakilaki menolak permintaan penutur perempuan dengan menggunakan pilihan kata yang kasar. Penolakan tersebut tentu memiliki pengaruh atau efek terhadap penutur perempuan. Sebuah penyampaian atau pernyataan berupa penolakan yang memiliki pengaruh atau efek kepada lawan tutur, merupakan bentuk tindak tutur perlokusi (Wiranty, 2015). Tuturan nirgender bahasa Sasak di atas merupakan bentuk tindak tutur perlokusi, karena memiliki efek kepada penutur perempuan.

Diksi umpatan memiliki maksud memerintah untuk berhenti berbicara. Penutur laki-laki memerintahkan penutur perempuan untuk berhenti berbicara menggunakan jenis kata dan ragam bahasa yang kasar. Ujaran tersebut tentu memiliki maksud, yaitu supaya lawan tuturnya tidak berbicara lagi. Tindak tutur tersebut dikatagorikan ke dalam tindak tutur ilokusi. Kentary dkk (2015) menyatakan tuturan yang bersifat menyatakan, menyuruh atau memerintah merupakan bentuk tindak tutur ilokusi secara eksplisit.

Diksi sangkalan mempunyai maksud penolakan terhadap lawan tutur dengan menggunakan pilihan kata yang 
kasar. Penolakan tersebut berupa ujaran dalam bahasa Sasak yang berbentuk sangkalan. Penutur laki-laki menyangkal pembicaraan penutur perempuan pada saat menjelaskan tentang nilai sosial budaya yang ada di masyarakat Sasak. Bentuk sangkalan tersebut dikatagorikan sebagai tindak tutur nirgender, karena tindak tutur tersebut terjadi bukan karena factor peran atau gender melainkan karena factor social. Masyarakat Sasak khususnya laki-laki terbiasa menyangkal menggunakan bahasa yang kasar.

Ketiga jenis diksi yang menyatakan hujatan, umpatan, dan sangkalan banyak terjadi karena perbedaan pilihan kata, ragam bahasa, dan situasi penutur dalam keadaan marah. Hal tersebut membuat penutur mengucapkan jenis kata yang kasar kepada lawan tutur dalam berinteraksi. Interaksi sosial di masyarakat Sasak, biasanya pilihan kata yang digunakan laki-laki lebih menekan lawan tutur (perempuan) sehingga dapat merugikan perempuan (Bakri, 2016). Keadaan tersebut tentu memunculkan bentuk tindak tutur nirgender dalam tuturan bahasa Sasak di masyarakat.

Dalam berkomunikasi antara penutur dan lawan tutur yang berbeda jenis kelamin secara sosial memerlukan etika dan kesopanan dalam tuturan. Menghargai lawan tutur, tidak saling merendahkan. Kenyataannya secara adat masih ada bentuk ketidaksetaraan. Laki-laki merasa mendominasi sehingga selalu diutamakan dan dihargai, sedangkan perempuan selalu dikesampingkan dan direndahkan. Belum ada penghargaan atau bentuk kesetaraan kepada penutur perempuan. Padahal dalam berkomunikasi hal yang mudah dilakukan adalah memilih diksi yang bermakna menghargai gender. Dengan demikian diksi berperan dalam menumbuhkan kesetaraan gender.

\subsubsection{Tindak Tutur Nirgender dalam Tuturan Bahasa Sasak Terkait dengan Isi Tuturan}

Tindak tutur nirgender dalam tuturan bahasa Sasak terkait dengan isi tuturan, terdapat jenis isi tuturan seperti: pelebelan, marginalisasi, dan diskriminasi. Pelebelan memiliki maksud untuk merendahkan lawan tutur atau penutur perempuan. Pelebelan yang berbasis gender di masyarakat Sasak cenderung berbentuk negatif terhadap perempuan. Pelebelan negatif banyak terjadi kepada perempuan Sasak, karena anggapan masyarakat bahwa perempuan adalah mahluk yang lemah (Khaerani, 2014). Anggapan tersebut adalah sesuatu yang lumrah bagi masyarakat Sasak, sehingga tidak 
heran jika masyarakat memegang teguh tradisi dan budaya patriarki. Atas dasar hal tersebut, bentuk ketidaksetaraan terhadap perempuan Sasak terjadi di masyarakat yang berbentuk pelebelan kepada perempuan.

\begin{tabular}{lcc}
\multicolumn{2}{c}{ Marginalisasi memiliki } & maksud \\
pembatasan & terhadap & penutur \\
perempuan. & Pembatasan & tersebut
\end{tabular}
hampir meliputi segala bidang dan kegiatan yang ada di masyarakat. Khaerani (2014) perempuan sasak merupakan pihak yang tidak dianggap penting dalam kegiatan yang ada di masyarakat dan pada sektor-sektor yang lainnya, kecuali pada sektor domistik. Adanya asumsi dan hasil konstruksi sosial di masyarakat, memunculkan bentuk marginalisasi terhadap perempuan dalam bergerak dan ikutserta pada kegiatan masyarakat.

Diskriminasi yang ada di masyarakat Sasak merupakan wujud dari budaya patriarki, yang kemudian menimbulkan bentuk perlakuan yang berbeda terhadap penutur perempuan dengan penutur laki-laki dan selalu mengutamakan penutur laki-laki dalam segala hal. Bentuk perlakuan yang berbeda tersebut tentu karena adanya faktor gender, yang menjadi dasar atau landasan masyarakat memberikan perlakukan yang berbeda kapada laki- laki dengan perempuan. Unsriana (2014) menyatakan gender merupakan basis terjadinya bentuk perbedaan perempuan dan laki-laki dari segi peran. Gender juga menjadi faktor yang membuat kedudukan perempuan lebih rendah dari laki-laki. Hal tersebut merupakan wujud dari ketidaksetaraan gender di masyarakat.

Tindak tutur nirgender dalam tuturan bahasa Sasak terkait dengan isi tuturan, terjadi karena isi tuturan yang cenderung merendahkan penutur perempuan. Isi tuturan tersebut merupakan hasil konstruksi sosial budaya masyarakat. Hasil konstruksi sosial tersebut, mampu mempengaruhi cara berpikir, keyakinan, dan perilaku masyarakat Sasak (Yusrini, 2017). Konstruksi sosial budaya pula membuat masyarakat selalu mengutamakan lakilaki dari pada perempuan dalam hal apapun, sehingga perempuan dinomorduakan atau dikesampingkan. Hal tersebut masih ada di masyarakat Sasak sampai saat ini.

Dalam komunikasi sehari-hari antara penutur dan lawan tutur yang berbeda jenis kelamin secara sosial budaya memerlukan etika dan kesopanan yang terkandung di dalam isi tuturan. Seharusnya saling menghargai dengan lawan tutur dan tidak saling 
merendahkan. Kenyataannya secara adat dan sosial budaya masih ada bentuk ketidaksetaraan atau ketimpangan. Penutur laki-laki selalu dihormati dan dihargai, sedangkan penutur perempuan selalu direndahkan. Belum ada bentuk kesetaraan antara penutur laki-laki dengan penutur perempuan. Padahal dalam berkomunikasi sangat penting dalam menyampaikan isi tuturan yang bermakna saling menghargai. Untuk itu, dalam memilih isi tuturan sangat berperan dalam mewujudkan kesetaraan gender.

\subsubsection{Tindak Tutur Nirgender dalam Tuturan Bahasa Sasak Terkait dengan Topik Tuturan}

Tindak tutur nirgender dalam tuturan bahasa Sasak terkait dengan topik tuturan, ditemukan jenis topik tuturan dalam bidang: pendidikan, pekerjaan, dan partisipasi. Topik tuturan pada bidang pendidikan memiliki maksud untuk memberikan pembatasan akses terdahap perempuan dalam bidang pendidikan. Dalam bidang pendidikan di masyarakat Sasak, laki-laki selalu menjadi prioritas utama. Natasha (2013) meyatakan masyarakat biasanya lebih mengutamakan laki-laki dibandingkan perempuan dalam bidang pendidikan. Perempuan Sasak biasanya dipinggirkan atau dikesampingkan di bidang pendidikan. Lain halnya dengan laki-laki yang memang selalu diberikan kebebasan untuk mendapatakan pendidikan tinggi.

Topik tuturan bidang pekerjaan memiliki maksud merendahkan penutur perempuan dalam hal pekerjaan atau kemampuan bekerja di luar rumah. Atas dasar hal tersebut, sangat minim perempuan Sasak bisa berkarier. Pada akhirnya, perempuan menjadi ibu rumah tangga atau pada sektor domistik. Perempuan Sasak selalu diidentikan dan dipantaskan pada sektor domistik saja (Yusrini, 2017). Meskipun ada yang memiliki kesempatan untuk bisa bekerja di luar rumah seperti kerja kantoran, tetapi setelah menikah mereka tetap hanya menjadi ibu rumah tangga dan bagian domistik. Berbeda dengan penutur lakilaki yang selalu bebas dalam memilih pekerjaan di mana saja. Hal tersebut tentu menimbulkan bentuk ketidaksetaraan gender pada bidang pekerjaan terhadap perempuan.

Bidang partisipasi memiliki maksud untuk memberi tekanan dan batasan kepada penutur perempuan. Adanya bentuk tekanan dan batasan dari pihak keluarga (orang tua) dan masyarakat secara umum yang membuat kurangnya partisipasi 
perempuan dalam kegiatan bermasyarakat. Untuk itu, biasanya laki-laki yang selalu mendominasi. Apalagi perempuan Sasak dikenal memiliki sikap kepatuhan kepada lakilaki. Perempuan Sasak tidak memiliki keberanian dan kepercayaan diri untuk bisa menyampaikan pendapat serta keinginannya (Nasri, 2018). Sikap perempuan yang tidak mempunyai kepercayaan diri dan selalu patuh pada laki-laki adalah salah satu faktor lakilaki menjadi penguasa dan bertindak semaunya. Kemudian hal tersebut memunculkan bentuk ketidaksetaraan gender terhadap perempuan di masyarakat Sasak.

Terakhir, tindak tutur nirgender dalam tuturan bahasa Sasak terkait dengan topik tuturan dalam bidang pendidikan, pekerjaan, dan partisipasi, terjadi karena konstruksi sosial budaya yang mempengaruhi cara berpikir dan berprilaku masyarakat Sasak. Pengaruh tersebut selalu memunculkan ketidaksetaraan terhadap perempuan, terutama dalam bidang pendidikan. Perempuan Untuk bisa mendapatkan pendidikan kejenjang yang lebih tinggi sangatlah minim, karena akses mereka dibatesi orang tua. Menurut Syafruddin (2018) terbatasnya akses bagi perempuan dalam dunia pendidikan, menyebabkan terjadinya ketidaksetaraan di masyarakat Sasak. Bentuk tindak tutur nirgender tersebut sudah dianggap biasa oleh masyarakat Sasak, bahkan mereka menganggap hal tersebut adalah hal yang benar dan tidak merasa bersalah. Oleh sebab itu, bentuk tindak tutur nirgender dalam dunia pendidikan tersebut masih ada sampai sekarang di masyarakat Sasak.

Masyarakat Sasak dalam berkomunikasi antara penutur dan lawan tutur yang berbeda jenis kelamin secara sosial budaya memerlukan etika dan kesopanan dalam tuturan. Menghargai lawan tutur, tidak saling merendahkan. Kenyataannya secara adat dan sosial budaya masih ada bentuk ketidaksetaraan. Laki-laki merasa mendominasi sehingga selalu diutamakan dan dihargai, sedangkan perempuan selalu dikesampingkan dan direndahkan. Belum ada penghargaan (kepada perempuan) atau bentuk kesetaraan. Padahal dalam berkomunikasi hal yang mesti dilakukan adalah memilih topik tuturan yang memiliki makna menghargai perbedaan peran (gender). Dengan demikian topik tuturan sangat berperan dalam menumbuhkan kesetaraan gender. 


\section{SIMPULAN}

Sesuai dengan rumusan masalah, tujuan penelitian dan hasil penelitian serta pembahasan terkait dengan "Tindak Tutur Nirgender dalam Tuturan Bahasa Sasak," maka dapat disimpulkan sebagai berikut:

1. Tindak tutur nirgender dalam tuturan bahasa Sasak terkait dengan diksi, ditemukan bentuk perbedaan pilihan kata dan ragam bahasa dalam diksi yang menyatakan umpatan, hujatan, dan sangkalan yang digunakan penutur laki-laki. Perbedaan tersebut terjadi karena faktor sosial budaya di masyarakat.

2. Tindak tutur nirgender dalam tuturan bahasa Sasak terkait dengan isi tuturan, terdapat bentuk ujaran atau tindak tutur yang cenderung merendahkan perempuan, seperti: pelabelan, marginalisasi, dan diskriminasi. Adapun penandanya adalah ragam bahasa yang digunakan penutur laki-laki yang cenderung merendahkan perempuan, yang disebabkan oleh sosial budaya masyarakat.

3. Tindak tutur nirgender dalam tuturan bahasa Sasak terkait dengan topik tuturan, diperoleh bentuk tindak tutur nirgender dalam bidang pendidikan, pekerjaan dan partisipasi. Penandanya adalah ragam bahasa yang digunakan penutur, yang disebabkan oleh faktor budaya dan tradisi.

\section{DAFTAR PUSTAKA}

Bakri. 2016. Analisis Percakapan Bahasa Sasak dalam Perspektif Gender: Sebuah Kajian Wacana Kritis. Aksara. Jurnal Bahasa dan Sastra. Vol.28, No.1.

Djajasudarma, Fatimah. 2010. Metode Linguistik: Ancangan Metode Penelitian dan Kajian. Bandung: PT Refika Aditama.

Hidayat, Toni Syamsul. 2010. Bahasa Sasak Halus dan Perilaku Sosial Masyarakat Penuturnya. Jurnal Ilmiah Bahasa dan Sastra: Vol.3, No.2

Juanda. 2018. Gender Phenomenon in Short Story by Fanny J. Poyk in Media On Line, Indonesia. Jurnal Of Gender Studies. Vol.8, No.2

Kentary, Ardina dkk. 2015. Tindak Tutur Ilokusi Guru Berlatar Belakang Budaya Jawa: Perspektif Gender. Jurnal Penelitian Humaniora. Vol.16, No.1

Khaerani, Siti Nurul. 2014. Potret Ketidakadilan Gender Pada Masyarakat Tradisional Lombok. Journal Publisher: PSGA LP2M IAIN Mataram. Vol.8, No.2.

Kuswarno, Engkus. 2008. Etnografi Komunikasi: Pengantar dan Contoh Penelitiannya. Bandung: Widya Padjadjaran.

Maulani, Aprizal dkk. 2018. Kekerasan Gender dan Nilai Pendidikan Karakter dalam Cerpen "Dua Dapur” Karya JM. Diana Darmansyah. Terakreditasi 
Kemenristekdikti

No.34/E/KPT/2018.

Nasri, Ulyan. 2018. Memotret Bias Gender dalam Konteks Sosio-kultural Lombok Menuju Sebuah Humanisme Sosial Spritual. Jurnal Pendidikan Islam. AlMunawwarah. Vol.10, No.2

Natasha, Harum. 2013. Ketidaksetaraan Gender Bidang Pendididkan: Faktor penyebab, Dampak, dan Solusi. Riau: Marwah. Vol.XII, No.1

Nurjamily, Wa Ode. 2015. Kesantunan Berbahasa Indonesia dalam Lingkunagn Keluarga (Kajian Sosiopragmatik). Jurnal Humanika. Vol.3 No.15

Rokhimah, Siti. 2014. Patriarkhisme dan Ketidakadilan Gender. Jurnal Muwazah. Vol.6, No.1

Sudaryanto. 1988. Metode Linguistik. Yogyakarta: Gadjah Mada University Press.

Sumarsono. 2017. Sosiolinguistik. Yogyakarta: Pustaka Pelajar.

Sumarsono. 2010. Pragmatik. Singaraja: Universitas Pendidikan Ganesha.

Sunardi. 2015. Tuturan Pengutan Guru dalam Wacana Kelas. Sidoarjo: Jembatan Merah (Jurnal Ilmiah Pengajaran Bahasa dan Sastra Indonesia). Vol.11

Syafruddin dkk. 2018. Peranan Pendidikan Gender dan Kesehatan Reproduksi untuk Mencegah Terjadinya Pernikahan Usia Dini (Pendidikan dan Penyuluhan pada Siswa Mts di Kecamatan Bayan Kabupaten Lombok Utara). Jurnal Pendidikan dan Pengabdian Masyarakat. Vol.1, No.2
Ulfatin, Nurul. 2015. Metode Penelitian Kualitatif di Bidang Pendidikan: Teori dan Aplikasinya. Malang: MNC Publishing.

Unsriana, Linda. 2014. Diskriminasi Gender dalam Novel Ginko Karya Junichi Watanabe. Jurnal Lingua Cultura. Vol.8, No.1

Wilian, Sudirman. 2006. Tingkat Tutur dalam Bahasa Sasak dan Bahasa Jawa. Wacana. Vol.8, No.1

Wiranty, Wiendi. 2015. Tindak Tutur dalam Wacana Novel Laskar Pelangi Karya Andrea Hirata (Sebuah Tinjauan Pragmatik). Jurnal Pendidikan Bahasa. Vol.4, No.2

Yusrini, Bq. Ari. 2017. Tenaga Kerja Wanita dalam Perspektif Gender di Nusa Tenggara Barat. Jurnal AlMaiyyah. Vol.10, No.1 